\title{
ARE "MODAL ADVERBS" AUTOMATICALLY MODAL MARKERS? THE CASE OF FRENCH CERTAINEMENT WITH ITS EPISTEMICO-MODAL AND ITS EVIDENTIAL USE ${ }^{1}$
}

\author{
PATRICK DENDALE \\ University of Antwerp \\ patrick.dendale@uantwerpen.be \\ ORCID: 0000-0003-2602-0686
}

\section{ABSTRACT}

The French adverb certainement ('certainly') is labelled a "modal adverb". It has two (sentence adverb) uses according to the literature, called "strong modal use" and "weak modal use". The strong modal use is indeed strong (epistemico-)modal in that it indicates total certainty, whether subjective or intersubjective. What is called its "weak modal use" is shown to be an evidential use. It indicates primarily that the content qualified by the adverb results from a non-monotonic inference, performed by the speaker, whose conclusions are plausible, defeasible, and thus never totally certain. This is due to the presence of an evidential-inferential component in its meaning. As for the so-called weak modal element of "probability" in its meaning, we reanalyse it as "noncertainty" and argue it is an element of utterance meaning, a property of quasi-assertions to which non-monotonically inferred content gives rise. Finally, we claim that the adverb also has a meaning component that we call "epistemic posture of certainty", shown to be different from epistemic modality. On the basis of three parameters and their values, we show how certainement can be interpreted, in a series of contextual configurations, either as an instance of its epistemicomodal use or of its evidential use.

KEYWORDS: French modal adverbs, certainement, markers of epistemic modality, markers of inferential evidentiality, epistemic posture of certainty, non-monotonic inference, evidential use.

\section{ELS “ADVERBIS MODALS” SÓN AUTOMÀTICAMENT MARCADORS MODALS? EL CAS DE CERTAINEMENT EN FRANCÈS EN L'ÚS EPISTÈMIC-MODAL I L'ÚS EVIDENCIAL}

RESUM

L'adverbi francès certainement ('certament, sens dubte') ha estat etiquetat com un "adverbi modal". D'acord amb la bibliografia, aquest adverbi té dos usos (com a adverbi oracional), anomenats "l'ús modal marcat" i "l'ús modal feble". L'ús modal marcat és clarament (epistemico-)modal ja que indica certesa total, tant si és subjectiu com intersubjectiu. En canvi, el que ha estat anomenat "ús modal feble" l'hem considerat un ús evidencial. Aquest ús indica principalment que el contingut qualificat per l'adverbi prové d'una inferència no-monotònica, elaborada pel parlant, les conclusions de la qual són plausibles, revocables i, per tant, mai del tot certes. Això es deu a la presència d'un component evidencial-inferencial en el seu significat lèxic.

\footnotetext{
${ }^{1}$ Many thanks to my colleagues and friends Antoon De Rycker, Laura Devlesschouwer, Johanna Miecznikowski, Zlatka Guentchéva, Jean-Pierre Desclés, Johan van der Auwera, Danielle Coltier, Amalia Rodríguez Somolinos, as well as to two anonymous reviewers for their careful reading, valuable comments and suggestions on this and a previous version of the article.
} 
Un segon component important en el significat és l'anomenat element modal feble de "probabilitat", el qual analitzem com un valor de "no-certesa" i argumentem que és un element del significat de l'enunciat (i no del significat lèxic de l'adverbi), una propietat de quasiasseveració a la qual dona lloc el contingut inferit no-monotònicament. Finalment, defensem que l'adverbi també té un component de significat lèxic que hem anomenat "postura epistèmica de certesa", que considerem diferent de la modalitat epistèmica. Tenint en compte els tres paràmetres i els valors corresponents, mostrem com pot ser interpretat certainement, en una sèrie de configuracions contextuals, tant en el cas de l'ús modal-epistèmic com de l'ús evidencial.

MOTS CLAU: verbs modals francesos, certainement, marcadors de modalitat epistèmica, marcadors d'evidencialitat inferencial, postura epistèmica de certesa, inferència nomonotònica, ús evidencial.

\section{INTRODUCTION}

The question at the outset of this research was: "Can French certainement, an adverb commonly labelled «modal», be considered evidential and become a regular member of inventories of evidential markers (cf. Wiemer \& Stathi 2010)?"2 Our answer to that question is "yes". It is based on an in-depth analysis of two uses of the French "modal" adverb certainement in authentic utterances. On the basis of that analysis, we advocate a homonymic treatment of polysemic certainement, in which the language item can be part of more than one inventory of markers; in our case, not only that of epistemico-modal ${ }^{3}$ markers but also that of evidential markers. The term "evidential marker" then refers in fact to one single use ${ }^{4}$ of the item rather than to the item as such. The research-strategic conclusion we draw from this analysis is that it is advisable to revisit all language items traditionally labelled "modal" (including the weak ones, such as peut-être que, 'maybe', il se peut que 'it is possible that', probablement 'probably'), to see if they do not have a use that would fall under the label "evidential", turning them into an evidential markers that have their place in inventories of evidential markers.

Certainement is a frequent ${ }^{5}$ French adverb, commonly labelled "modal adverb"6 (Meunier 1974: 8, Molinier 1990: 32, Anscombre 2013: 73), "adverb of modality" (Sueur 1976, Guimier 1996: 11, Gezundhajt 2000: 219) or "epistemic adverb" (Stage 2002: 45, Gosselin 2010: 329). It contains a lexical morpheme,

2 Early reflections on this topic trace back to a master's thesis of one of my students, Isabelle Goris (2008-2009), whom I wish to thank for having stimulated my curiosity in this topic.

${ }^{3}$ Since modal is not limited to epistemic modality alone, I will use epistemico-modal throughout this article.

${ }^{4}$ What we call use (of an item) refers to the combination of a series of specific syntacticosemantic configurations in which the item can appear and a specific meaning it then has.

5 The text base frTenTen12 contains 109,8 occurrences per million words (1,25 million occurrences in total), more than for probablement, a bit more than sans doute, but nearly half fewer than peut-être.

${ }^{6}$ In the same way, incidentally, devoir is also called a "modal verb". 
certain, which explicitly refers to an (epistemico-)modal notion, whose function is "to evaluate the truth or degree of certainty of the proposition it accompanies, on a necessarily positive scale" (Molinier 1990: 92, our translation) - a definition of epistemic modality (see section 3.1).

French dictionaries distinguish at least two meanings for certainement. One is described in terms of "absence of doubt", the other in terms of "absence of (absolute) certainty" or "(strong) probability". . But what is important is that both are captured in epistemico-modal terms. Linguistic studies, too, propose two related but opposing meanings, a strong modal meaning and a weak modal meaning. For Dignoire, for instance, the adverb "possède à présent deux sens attestés" ('has nowadays two recognized meanings'), called "certainty" and "probability" (1969: 50). ${ }^{8}$ This has thus been the standard analysis for roughly 50 years. The strong modal meaning is directly connected to the meaning of the adjective certain and the noun certitude (Bacha 1998: 27, Vion 2004: 102), as they are used, in (1)-(3):

(1) Quand je te disais que «le pouvoir» n'existe pas, je le pressentais, mais je n'en avais aucune preuve. Maintenant c'est certain. (frTenTen12)

'When I told you that "power" does not exist, I sensed it, but I had no proof at all. Now it is certain.'

(2) Nous avons repêché deux corps dans le lac, dont celui de la mère de L'Adolescent fou. Mais lui, n'y était pas. Brad : Vous êtes sûr d'avoir bien sondé le lac ? Inspecteur Jenny : J'en suis sûr et certain. (frTenTen12)

'We recovered two bodies from the lake, including that of the crazy Adolescent's mother. But he himself was not there. Brad: Are you sure you sounded the lake carefully enough? Inspector Jenny: I'm dead sure of it.'

(3) Que dire de nos voiles en triangle? Une certitude est qu'elles sont très anciennes. (frTenTen12)

'What about our triangular sails? One certainty is that they are very old.'

The weak modal meaning, however, isn't directly connected anymore to the meaning of the adjective certain. In the following examples, ${ }^{9}$ it is difficult to claim that the adverb expresses "total certainty" or even "total subjective certainty".

${ }^{7}$ Two examples:

"1. D'une manière certaine" ['In a way that is certain'] versus " 3 . Très probablement, mais sans certitude absolue" ['Very probably but without absolute certainty'] (Rey-Debove \& Rey 1993: s.v. certainement); “[certainement] exprime ou renforce une affirmation telle qu'elle n'offre de prise à aucun doute" ['expresses or reinforces an assertion such that it offers no doubt at all'] versus "[...] souligne le caractère probable d'une assertion [...]" ['underlines the probable nature of an assertion'] (Trésor de la Langue française informatisé, s.v. certainement).

${ }^{8}$ Cf. also Vion (2001: 222-223), Féron (2002: 23), amongst others.

${ }^{9}$ Our examples come from the "text bases" frTenTen12 (Sketch Engine) and Frantext, from Google Books, Google Scholar and Google Actualités and from the Internet in general. The study results from an initial systematic observation of 400 occurrences taken in the first two text bases and from a whole series of more precisely targeted corpus searches in the other text collections. 
Nowadays, occurrences of this type represent the most frequent use ${ }^{10}$ of the adverb:

(4) Reste à l'appareil... J'entends quelqu'un qui rentre. C'est certainement ta mère... (Simenon 1967: 406, GBooks)

'Stay on the phone... I hear someone coming home. It surely ${ }^{11}$ is your mother...'

(5) Et le cadeau le plus nul? Je ne sais pas, certainement de la vaisselle ou des trucs inutiles qu'on t'offre quand on a pas d'idées et qu'on te connait mal. (frTenTen12)

'And the most useless gift? I don't know, surely dishes or useless stuff that people offer you when they have no ideas and they don't know you well.'

(6) O'Brien le connaissait certainement, car il avait un léger battement de paupières, mais il ne dit rien. (Simenon 1968: 219, GBooks)

'O'Brien surely knew him / must have known him because he blinked slightly but said nothing.'

The challenging question then is: Where does that so-called "weak modal meaning" of certainement come from? Traugott's claim that "weaker epistemicity precedes stronger epistemicity" (1989: 46), illustrated by the author with the modal adverb evidently, does not seem to be applicable here. Féron (2002: 29) suggests that this hypothesis does not hold for the semantic evolution of sentence adverbial certainement from "certainty" to "probability". In our study, we suggest another possible explanation for the emergence of the "weak modal" meaning and the link between the two meanings and uses of certainement (see section 4.2.2).

The outline of this article is as follows. In section 2, we formulate the central hypothesis of our study and give two sets of preliminary examples. We then define the key notions of our analysis: epistemic modality and inferential evidentiality (section 3). These are necessary to give a full semantic description of the two uses of certainement in section 4 . In section 5, we will examine how certainement is interpreted in context and propose a procedure of interpretation based on parameters, values and "co(n)textual" configurations. The conclusions are given in section 6 .

\footnotetext{
${ }^{10}$ We did not collect quantitative data - which was not the aim of this article - but this observation is overwhelmingly evident for everyone who takes a look at the data in French.

${ }^{11}$ The meaning of English certainly appears to be stronger in many cases than that of French certainement in its "weak" use. Surely most often seems nearer to French certainement (see Downing 2001). A translation with probably could also be adequate in some cases. Even so, we argue in section 4.2.2 that the meaning of certainement is different from that of probablement, so we will render "weak" certainement in the examples by surely and the strong one by certainly.
} 


\section{CENTRAL HYPOTHESIS WITH PRELIMINARY EXAMPLES}

The central hypothesis of this study is that the "modal" adverb certainement, when it has the status of a sentence adverb, ${ }^{12}$ has two uses and that these are not both "modal" in nature. The least frequent use in contemporary French is indeed epistemico-modal (hence certainement $\mathrm{M}_{\mathrm{M}}$. The other one, however, the most frequent nowadays, is not. Our claim is that it is evidential in nature ${ }^{13}$ (hence certainement ${ }_{E}$ ). It belongs to the sub-type "Inferring" (Willett 1988) or "Inferred/Assumed" (Aikhenvald 2004). Analyzing it in evidential terms is intuitively and theoretically more adequate and has greater explanatory power than analyzing it in epistemico-modal terms. This is probably also the case for a whole range of other so-called "modal" expressions, even weak ones (e.g. peut-être que 'maybe').

Let us first consider two preliminary series of examples to illustrate the two uses of certainement.

First series:

(7) Les dernières vacances en France de mon père dataient de 1950. Une photographie, certainement prise par mon grand-père, montre ma grand-mère, les quatre enfants. (Audin 2012, Frantext)

'My father's last holiday in France was in 1950. A picture, surely taken by my grandfather, shows my grandmother, the four children.'

(8) Il tourne la cuiller dans le café, certainement froid depuis longtemps. (Tenenbaum 2008, Frantext)

'He turns the spoon in the coffee, which surely has long become cold.'

(9) Pourquoi est-ce qu' on me gardait comme flic ? Je ne sais pas, certainement parce que j'ai déjà été bon, et que des gens croient en moi. (frTenTen12)

'Why did they keep me as a cop? I don't know, surely because I've been good before, and people believe in me.'

(10) Il pense certainement qu'avec moi, il a affaire à un idiot, un type à qui l'on ne peut confier la moindre responsabilité. (frTenTen12)

'He surely thinks that with me, he is dealing with an idiot, a bloke who cannot be entrusted with the least responsibility.'

Certainement in examples like (7)-(10) will be shown to express inferential evidentiality, as it will be defined in section 3.2. The adverb, when used in

${ }^{12}$ We leave aside in this study the manner adverb use of certainement, as in examples like:

(i) “Ceux qui n'étaient pas atteints s'enroulaient dans les draps des pestiférés afin de mourir certainement" ['Those who were not wounded rolled up in the sheets of the plague victims in order to die certainly']. (Camus 1947, cited by TLFi, s.v. certainement) (See also Féron 2002: 25).

${ }^{13}$ As far as English certainly is concerned, according to Simon-Vandenbergen (2008), it is not evidential but epistemico-modal: "Semantically, certainly is a «neutral» adverb of certainty, simply expressing that the state of affairs is considered to be certain. It does not, in contrast with say clearly or obviously add an evidential dimension." (2008: 1531, our emphasis). 
examples like these, must be categorized as an "inferential evidential marker". What this implies will be shown in section 4.2.

Second series:

(11) Les Érétriens certainement, et probablement les Athéniens, se trouvaient parmi les forces grecques, mais les textes sont peu explicites sur ces événements. (Eustathios Raptou 1999, GBooks)

'The Eretrians certainly, and probably the Athenians, were among the Greek forces, but the texts are not very explicit on these events.'

(12) As-tu une souffleuse à neige ? - Certainement! (frTenten12)

'Do you have a snow blower? - Certainly!'

(13) Il ne connaissait pas de Malabe. Un flic? Plus certainement un indic. (Izzo 1995, Frantext)

'He did not know a Malabe. A cop? More certainly an informant.'

The meaning of certainement in examples (11)-(13) corresponds to the functional definition of epistemic modality, which we present in section 3.1. The adverb, when used in examples like these, will be categorized as an 'epistemicomodal marker'.

\section{THE NOTIONS OF EPISTEMIC MODALITY AND (INFERENTIAL) EVIDENTIALITY}

Before moving on to a detailed semantic analysis of these two uses (section 4), let us define the two key notions of our analysis.

\subsection{Definition of epistemic modality}

In a functional perspective, epistemic modality links a proposition, information, content, a thought or a description of a state of affairs to an epistemic scale, representing degrees of certainty or degrees of probability. In a logical or formal perspective, on the contrary, it links a proposition to one of the two notions of the Aristotelian dichotomy necessity/possibility ${ }^{14}$ applying mechanisms to reduce or relativize the absolute value of necessity. We define epistemic modality as follows:

Epistemic modality refers to the qualification of a propositional content (thought or uttered) in terms of degrees of subjective or intersubjective certainty, or in terms of degrees of objective or subjective probability.

This qualification can be thought of as a dynamic process of estimation or calculation performed by the speaker (at the moment of production) or the hearer (at the moment of interpretation), or as a static label, which is attached to propositional content without

${ }^{14} \mathrm{Cf}$. De Haan: "Epistemic modality is concerned with the areas of possibility and necessity, which are referred to as weak and strong epistemic modality, respectively" (2001: 203, our emphasis). 
necessary indication of who was (originally) responsible for the process of epistemic estimation. ${ }^{15}$

The epistemic qualification can be communicated linguistically at the level of the utterance in various ways: it can be predicated, shown, presupposed, entailed, implicated, suggested or signalled multimodally.

In studies on the linguistic marking of epistemic modality the one who performs the epistemic qualification is typically the speaker (I am certain that, certainly) or the represented speaker (e.g. in reported direct discourse), but it can be any person (For John, there is not any doubt that...). Some language items have as their primary lexical use the indication of the degree of certainty or probability (e.g. Je suis certain que, certainement $t_{M}$ ). Others have it as a component (primary or not) in their morphological meaning (e.g. Je crois que, 'I think', Je parie que 'I bet that', Mon hypothèse est que, 'My hypothesis is that') or express it as an entailment (e.g. certainement $t_{\text {) }}$ or an implicature (e.g the reportive conditional, Dendale 2018) at the level of utterance meaning. It can also be suggested by the content of the sentence (e.g. content about future states of affairs).

\subsection{Definition of evidentiality and inferential evidentiality}

In a functional perspective, evidentiality as a notion is fundamentally different in nature from epistemic modality (inter alii Dendale 1991: 50, De Haan 1999, Aikhenvald 2004: 6-8, Cornillie 2009: 46, Boye 2012: 2). Linguistic markers of evidentiality, however, can have epistemico-modal elements in their meaning structure, as is the case with certainement (see section 4.2.3). We will define the notion as follows:

Evidentiality refers to the 'source of information' of a propositional content, viz. the epistemological operation by which a perceived state of affairs is brought to the knowledge of the speaker (by direct perception), a propositional content is directly received by her/him from others (by report) or knowledge was newly created in her/his mind (by inference).

Direct perception, report and inference are the three main epistemological operations to which the cover term "source of information" refers, one of the main defining terms of evidentiality. Inferential evidentiality, referring to the epistemological operation of inference, important for this study, is expressed by inferential evidentials:

${ }^{15}$ In a sentence like (i), probablement is nothing more than an epistemic label, attached to encyclopedic content by the author of the article. It is impossible to know who estimated this information as (only) "probable":

(i) Eustathe de Thessalonique [...] est un érudit et ecclésiastique byzantin du XIIe siècle, probablement mort en 1198. (Wikipédia s.v. Eustathe de Thessalonique) 
Inferential evidentials indicate that the content they qualify is the result of an inferential operation of a specific type, performed by the speaker on the basis of pieces of information, often called premises or clues.

Example (14) illustrates the operation of inferential reasoning - made explicit in (15) - that starts from the observation of the missing circumflex accents in a text and leads to the conclusion, marked by certainement, that the typewriter plausibly did not come from France:

(14) Cette petite machine mécanique, où donc l'avait-il dégottée ? Certainement pas apportée de France, puisque dans les pages du mémoire les accents circonflexes ont été rajoutés à la main sur l'original. (Perrut 2009, Frantext)

'Where did he find this little mechanical typewriter? Certainly not brought from France, since in the pages of the thesis, the circumflex accents were added by hand onto the original.'

(15) a. This text has no typewritten circumflex accents, but has manually added ones.

b. If the typewriter had had the circumflex accent key, the author would have used it (because typewritten accents are preferable to manually added ones).

c. [Conclusion from $\mathrm{a}+\mathrm{b}$ :] The typewriter plausibly did not have a circumflex accent key.

d. Typewriters coming from France, usually have accent keys.

e. (Conclusion from $c+d)$ The typewriter plausibly did not come from France.

The nature of inference to which inferential evidentials refer and that we call evidential inference has long been claimed to be fundamentally abductive ${ }^{16}$ by French scholars J.-P. Desclés and Z. Guentchéva (e.g. Guentchéva 1994, Desclés 1996). ${ }^{17}$ In work in preparation, we try to show, however, that abduction as it is conceived by these authors does not cover all the forms of inference that inferential evidentials - including certainement - seem to mark. We found out that evidential inference is akin to the inference that is referred to in the literature of epistemology, logic, artificial intelligence, argumentation and the philosophy of scientific discovery with terms such as abduction (Peirce 1931-1935, Desclés \& Guentchéva 2001, 2018), retroduction (Peirce 1931-1935), hypothesis (Peirce 19311935, Harman 1965), conjecture (Ma \& Pietarinen 2018), abductive guess (Andersen 2016), presumption (Rescher 2006), presumptive inference or presumptive reasoning (Walton 2001), inference to the best explanation (Harman 1965), defeasible reasoning (Pollock 1987), plausible reasoning (Polya 1989), heuristic reasoning (Polya 1989), heuristic syllogism (Polya 1989), default reasoning (Reiter 1978,

\footnotetext{
16 "Les langues encodent en grammaticalisent des raisonnements abductifs" (Desclés 1996: 39) ['Languages encode and grammaticalize abductive reasoning'].

17 Most scholars working on inferential evidentiality characterize the nature of evidential inference not by a characterization of the inferential operation but through a typology of the evidence on which the operation is based. In another study we show the problems of this approach.
} 
Etherington \& Crawford 1999), etc. ${ }^{18}$ What unifies the inference referred to by all these terms is that it is fundamentally non-deductive or non-monotonic ${ }^{19}$ (McDermont \& Doyle 1980, Stalnaker 1980/1993). This means that its conclusions do not follow necessarily from the premises and are thus not necessarily true (as is normally the case in deduction). They are plausible (Desclés 1996, Molinier \& Levrier 2000, Walton 2001) and defeasible instead (Pollock 1987):20

\footnotetext{
dans les phrases où figure l'adverbe [certainement and sûrement], nous ne sommes plus dans la catégorie modale (épistémique) du certain, mais dans celle du plausible. (Molinier \& Levrier 2000: 94) $)^{21}$
}

Reasoning is defeasible when the corresponding argument is rationally compelling but not deductively valid. [...] In other words, the relationship of support between premises and conclusion is a tentative one, potentially defeated by additional information. (online Stanford Encyclopedia of Philosophy, s.v. Defeasible Reasoning)

The evidential component of certainemente can be paraphrased as 'I assume that, I presume that, I guess that, I bet that'.

\section{SEMANTIC DESCRIPTION OF THE TWO USES OF CERTAINEMENT}

In this section we give a detailed description of the meaning elements that play a role in the semantics of the two uses of certainement. Let us start with the epistemico-modal use, whose meaning is much less complex than that of its evidential use. It has only one meaning component.

\subsection{The meaning of epistemico-modal certainement (certainement $t_{M}$ )}

In all the contexts, except one, in which an instance of the epistemico-modal use of certainement (certainement $t_{M}$ ) is recognized, the adverb expresses the highest degree of certainty the speaker attributes to the content: "total certainty" or "absence of doubt". This is the degree of certainty predicated in utterances like

${ }^{18}$ All these terms are of course not synonyms of each other. They highlight different properties of a specific set of inferences, that in our view, are typical of evidential inferentiality and whose very nature has hardly been the topic of focused research in studies on evidentiality (with the exception of the work of Desclés and Guentchéva since the early 1990s).

${ }^{19}$ Cf. Morgan (2000): "Conclusions reached using common sense reasoning from a set of premises are often subsequently revised when additional premises are added. Because we do not always accept previous conclusions in light of subsequent information, common sense reasoning is said to be nonmonotonic" (p. 321) and "Most common sense reasoning about everyday matters seems to be nonmonotonic" (p. 322) (our italics).

20 We cannot develop these properties here. For a more elaborate study of the nature of evidential inference and its characteristics, see Dendale \& Miecznikowski (in preparation).

21 Translation: 'in sentences where the adverb [certainement and surement] appears, we are no longer in the epistemico-modal category of certainty, but in that of plausibility'. 
(1)-(3) due to the presence of the adjective certain ${ }^{22}$ and the noun certitude. What is referred to as "total certainty" can be:

(a) individual, subjective certainty (viz. inner conviction by the speaker: I am certain that/Our expert is certain that...),

(b) intersubjective certainty (viz. shared by a group of people or even universally: It is certain that we will all die one day or another).

There is one exception to the claim that certainement $\mathrm{m}_{M}$ expresses total certainty: when certainement is used in comparative constructions with plus 'more' (13) or moins 'less' (16):

(16) Pour les fournitures [en bois d'ébénisterie], Google peut t'aider mais moins certainement que l'artisan chez qui tu travailles. (frTenTen12)

'For [cabinet wood] supplies, Google can help you but less certainly than the craftsman you work with.'

In those constructions, the interpretation of total certainty is blocked, but this use of the adverb remains epistemico-modal: it still serves to indicate, by a secondary predication, an epistemic qualification of the content in terms of degrees of certainty. Instead of referring to a value at the top of the epistemic scale, certainement in those constructions refers to a value relative to another one on the same epistemic scale, higher or lower. What happens in those constructions is that the meaning of certainement becomes "unmarked" as to the precise degree of certainty it expresses. This is a behavior we observe also in other words (e.g. nouns) referring to scales. When asking (17), we do not claim that the wall is long, high or thick and (18) is a possible reply to it:

(17) Quelle est la longueur, hauteur et épaisseur du mur? ${ }^{23}$

'What is the length, height and thickness of the wall?'

(18) Il n'est pas très long, pas très haut, pas très épais.

'It is not very long, not very high, not very thick.'

The adjective certain, the noun certitude and the adverb certainementm can all be used both with an unmarked meaning (referring to whatever value along the certainty scale relative to another one) and a marked meaning (referring to the highest value on the scale). ${ }^{24}$

Note that certainement in the comparative of equality (with aussi: aussi certainement que 'as certainly as'), does not necessarily have the unmarked

\footnotetext{
${ }^{22}$ Corpus data gathered so far show that parenthetical c'est certain, in final position, is equivalent

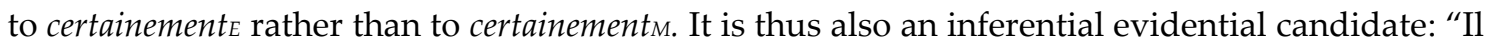
n'a pas compris ma question, c'est certain" ['He didn't understand my question, that is certain'].

${ }^{23}$ Those nouns do not even have negative counterparts with a spatial meaning that could be used in neutral questions like (17): ${ }^{*}$ courteur, ${ }^{*}$ bassesse, *étroitesse.

${ }^{24}$ This is not the case for their negative counterparts (incertitude 'uncertainty' and incertain 'uncertain'), which are always marked for low certainty.
} 
interpretation that the comparatives of superiority and inferiority have. Despite being relative also, it can express without problem the highest certainty, as (19) shows:

(19) Le bonheur à l'état sauvage, que l'on transcende en «bonheur naturel» n'est donc pas une chimère. Il existe aussi certainement que les Hottentots ne sont pas une fable. (frTenTen12)

'Happiness in the wild, which we transcend into "natural happiness", is therefore not a pipe dream. It exists as certainly as the Hottentots are not a fable.'

It is important, in the transition to the evidential use treated in the next

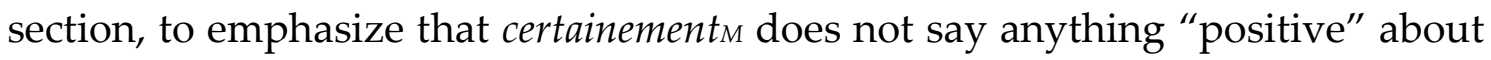
the way the speaker acquired the information - whether by direct perception or by report. In (20), for instance, the epistemico-modal certainty of the content "David Lynch is crazy" is founded by the context on two "evidential sources": the speaker's personal experience (Personnellement, je trouve que...) and David Lynch's own words:

(20) Est-ce que David Lynch est fou? Oui certainement, d'ailleurs lui-même le dit! Personnellement, je trouve que c'est un fou génial mais franchement comment faitil pour être aussi déconcertant ? (frTenTen12, our emphasis, original spelling)

'Is David Lynch crazy? Yes certainly. Moreover, he himself says so! Personally, I think he's a great crazy man, but frankly, how does he manage to be so disconcerting?'

In short, the semantics of certainement $\mathrm{m}_{\mathrm{m}}$ only has one semantic component in its lexical meaning, an epistemico-modal component, expressing total certainty. It does not indicate the type of source of information for a given content. Possible paraphrases of the adverb in this use are: (Pour moi) cela est (absolument) certain, de cela je suis certain, ce qui est certain c'est, ... dont il est certain que, ce qui est certain c'est que, ceci est une certitude, je peux dire cela avec certitude.

\subsection{The meaning of evidential certainement (certainement $)_{\text {) }}$}

The meaning of evidential certainement is more complex, for two reasons. First, there are three and not just one element of meaning in the semantics of certainement.. Second, these three meaning elements are of different types.

\subsubsection{Primary meaning component of "inferential evidentiality"}

A first element in the meaning of certainemente is an evidential component of inference, more precisely of non-monotonic or non-deductive inference, which we postulate to be part of the adverb's lexical meaning. Thanks to this component, the presence of certainement $\mathrm{in}$ an utterance gives that utterance the status of "conclusion obtained by the speaker through inference" and prevents it from having the status of "description of a state of affairs directly perceived by 
the speaker her/himself" - as is shown by the inappropriateness of $(21)^{25}-$ and the status of "content from a verbal report made to the speaker by somebody else" - as is shown by the inappropriateness of (22). ${ }^{26}$ It finally prevents the utterance from indicating that the communicated content was simply retrieved "as such" from the speaker's previously memorized stock of information:

(21) [While observing the rain] ?? Il pleut certainement.

'?? It surely is raining.'

(22) Paul est certainement dans son bureau. ?? Je viens de l'apprendre.

'Paul is surely in his office. ?? I just heard it.'

Let us illustrate these elements of meaning with example (8), reproduced here:

(8) Il tourne la cuiller dans le café, certainement froid depuis longtemps. (Tenenbaum 2008, Frantext)

'He turns the spoon in the coffee, which surely has long become cold.'

The speaker, who is observing a person stirring his coffee, makes a reflection about the temperature of the coffee. The presence of certainement $\mathrm{in}$ the utterance prevents the latter from being interpreted as stemming from a direct sensory perception (including a tactile one) of the coffee by the speaker. ${ }^{27}$ The presence of certainemente does not suggest neither that the other person told the speaker that his coffee had long become cold. The only possible interpretation with that use of the adverb is that of the utterance constitutes a plausible conclusion drawn by the speaker from encyclopedic elements of knowledge (how long it takes for a hot coffee to become cold, how long the coffee has been on the table...), but defeasibly. ${ }^{28}$ That is what the presence of the adverb indicates.

We consider the evidential component to be the most important (primary) component in the lexical meaning of certainementE. ${ }^{29}$ For that reason, we qualify this use of the adverb as evidential (certainement $t_{\text {) }}$ rather than as weakly modal, as many authors do. It is also this meaning component that justifies the categorization of certainemente as a marker of inferential evidentiality, viz. a

${ }^{25}$ In that sense certainemente is nearer to French à coup sûr 'surely' than to bien sûr 'obviously', both studied in Anscombre (2013).

${ }^{26}$ The test in (21) is based on Von Gintel \& Gillies' test for must (2010: 353) and Anscombre's test for à coup sûr / bien sûr (2013: 81). The test in (22) is based on Miche \& Lorda's test for sans doute (2014: 45).

${ }_{27}$ Without certainement, such an interpretation wouldn't have been impossible, linguistically (e.g. the speaker has touched the cup).

${ }^{28}$ Maybe, while the speaker was away for a while, they changed the coffee for a new one. Maybe it is in a super isolating cup. All that would defeat the normally drawn conclusion.

${ }^{29}$ Our analysis leads to another conclusion than the (provisional) one drawn by Byloo, Kastein \& Nuyts about Dutch zeker: "hence inferential meaning is strongly invited, and might thus be no more than an implicature. This is an issue for further research". (2006: 53) 
language item that, by virtue of its lexical meaning, refers to the epistemological operation of inference carried out by the speaker.

Appropriate paraphrases of the adverb in this use are: 'I assume that, I presume that, I guess that, I bet that, I'd lay odds that'.

\subsubsection{The utterance meaning element of "non-certainty"}

We saw above (cf. section 1 and note 7 ) that the use of certainement labelled here certainemente is described in the literature in terms of "(strong) probability" or "absence of (absolute) certainty". Let us call this certainemente's "non-certainty" element of meaning. The following examples make this explicit through the assertion même de cela je ne peux être sûr 'even of that I cannot be sure':

(23) Peut-être était-il allé montrer à ses parents les articles publiés sous son nom, certainement ceux-ci s'en sont montrés heureux et fiers, certainement ils ont pensé que, comme il l'avait promis lorsqu'il avait quitté Autun, il faisait bien mieux dans le civil qu'il aurait fait dans l'armée. Certainement. Sauf que, même de cela, que j'imagine sans mal, je ne peux être sûre. (Audin 2013, GBooks)

'Perhaps he had gone to show to his parents the articles published under his name, they surely were happy and proud of them, they surely thought that, as he had promised when he had left Autun, he was doing much better in civilian life than he would have done in the army. Surely. Except that even of that, which I can imagine without difficulty, I cannot be sure.'

What is the status of that non-certainty element of meaning? Our claim is that it is not part of the lexical meaning of the adverb, unlike the evidential meaning element described in 4.2.1 and the meaning element described below in 4.2.3. It could be strange, although not strictly impossible, to claim that the adverb certainement, containing the morpheme certain means 'this is NOT certain'. We think there is a less paradoxical explanation for this meaning element. We claim that non-certainty is an element of meaning expressed at the level of the utterance. Certainemente - because of its inferential-evidential meaning component - gives the content it has scope over the status of a hypothesis, ${ }^{30}$ presumption, conjecture, supposition, surmise or guess, in short, a nonmonotonically inferred conclusion. A hypothesis - defined as "an idea or explanation of something that is based on a few known facts but that has not yet been proved to be true or correct" (Oxford Learner's Dictionaries) - is known not to be "totally certain" 31 (yet). Hypotheses are by nature (only) plausible and they are defeasible. CertainementE "shows" that the content it has scope over has the status of a hypothesis, in a way similar to the way full assertions "show", as a property of their illocutionary force, that their propositional content is true. CertainementE turns the utterance in which it appears into a "quasi-assertion" (McDowell 1991),

\footnotetext{
${ }^{30}$ Etymologically, a hypothesis is a hypo-thesis, viz. something less sure than a "thesis".

${ }^{31}$ The information may appear fairly certain, but that's where the next component comes in (see section 4.2.3).
} 
rather than a full assertion, causing it to be interpreted as non-certain. This is well illustrated by example (24): in the absence of the body, the man cannot be categorically declared, viz. asserted dead, only declared "presumably dead" (certainement mort), viz. quasi-asserted dead. His death remains uncertain:

(24) Un jour que Moprwenna est rentrée à la maison, il [= l'oncle Dulwitch] avait disparu. Depuis, elle le cherche en vain. - Alors il n'est pas mort ? - C'est tout comme. Il est certainement mort, répondit sa mère. - Certainement mort ? - Oui. En l'absence de corps, on ne peut le déclarer que certainement mort. (Jones 2018, GBooks)

'One day when [Aunt] Moprwenna came home, [uncle Dulwitch] had disappeared. Since then, she has been looking for him in vain. - So he is not dead? - It's just as if. He surely is dead, replied his mother. - Certainly dead? - Yes. In the absence of a body, it can only be declared surely dead.'

Moreover, as we will see further (section 5), the content qualified by certainemente is most often not directly observable by the speaker, only "guessable" or "hypothesizable" (see section 5.2) and thus plausible, defeasible ${ }^{32}$ and non-certain by nature. Let us show how all this works, by comparing (25a) with its modified version $(25 b)$ :

(25) a. Mon interlocutrice était certainement plus âgée que moi, mais la confusion était telle que j'avais du mal à ne serait-ce que mettre un âge sur son visage. (frTenTen12)

'My interlocutor surely was older than me but the confusion was such that I could hardly even put an age on her face.'(frTenTen12)

b. Mon interlocutrice était plus âgée que moi.

'My interlocutor was older than me.'

With (25a), we understand that the speaker does not know the age of her/his interlocutor; s/he is not even able to put an age on her face. The age of someone is known to be a property not knowable from the outside. All that the speaker can do in that situation is guessing, conjecturing, hypothesizing the relative age of the other person, inferring it on the basis of observations and/or other pieces of knowledge. If the speaker knew her age, s/he normally would have said (25b), without certainemente. The reason for that is that the standard 33 "epistemic" interpretation of an unmarked, asserted utterance in the indicative (25b) is that the speaker knows what $\mathrm{s} /$ he says ${ }^{34}$ and presents this as simply true (Frajzyngier 1985: 243). This is not the case with quasi-assertions, to which hypotheses belong (McDowell 1991).

\footnotetext{
${ }^{32}$ It is namely possible that the lady only looks older than she really is. Appearances are always defeasible, as was clearly shown by Musi (2014) and Miecznikowski \& Musi (2015).

${ }^{33}$ We say "standard" because it is not impossible to use an evidentially unmarked utterance when making a confident guess, not making explicit its inferential character.

${ }^{34}$ To utterance (25b), an interlocutor could indeed react, in amazement: "Ah ! Tu connais son âge !?" ['Ah! You know her age!?'].
} 
That we call this meaning element of certainemente its "non-certainty" element, rather than its "probability" element (as most often in the literature), has to do with the fact that one of the main properties of non-monotonic inference is plausibility (cf. Desclés \& Guentchéva 2001), not probability. Probability is a term that has a "positive" orientation (tending towards certainty), rather than a "negative" one (not attaining certainty), which it means here. Another reason is that "non-certainty" as a term offers a better contrastive characterization of the two uses of certainement: certainement $t_{M}$ expresses certainty, certainemente noncertainty.

\subsubsection{Secondary meaning component: "epistemic posture of certainty"}

We further postulate that certainementE's meaning element of non-certainty is counterbalanced by a component that we also claim to be part of its lexical meaning and which will be called epistemic posture of certainty. ${ }^{35}$ The idea came from observing the noticeable difference in interpretation between utterances containing certainemente (26a), and utterances containing semantically near probablement $^{36}(26 \mathrm{~b})$, and devoir (26c):

(26) a. Il pense certainement que je suis con.

'He surely thinks that I'm stupid.'

b. Il pense probablement que je suis con.

'He probably thinks that I'm stupid.'

c. Il doit penser que je suis con.

'He must think that I'm stupid.'

Despite the meaning element of non-certainty in utterances with certainement $_{E}$, these utterances are consistently interpreted as expressing higher certainty than utterances with probablement or with epistemic devoir, two items that are both paraphrased as 'probablement' in the specialized literature, ${ }^{37}$ just like certainementE (see section 1). How can this impression of higher certainty be explained? One could think of arguing that certainemente is to be placed (a bit) higher up on the epistemic scale than probablement, ${ }^{38}$ meaning 'very probably' (see section 1), rather than dimply 'probably'. But how to measure or feel that subtle

35 Of the term "epistemic posture", which gave us 242 hits on GScholar on May 8th, 2020, in a wide variety of disciplines (philosophy, psychology, information sciences, pedagogy and education studies, political studies, religion studies, law studies, discourse studies, etc.), the only use near to the one it has here is in Cassam 2018, writing on epistemic insouciance.

${ }^{36}$ One of the anonymous readers suggested adding sans doute. We presume, however, without having studied the question yet, that sans doute (lit. 'without doubt') -although most often paraphrased as 'probablement' - could be another candidate for having a component of posture of certainty. That could be an important feature distinguishing it from probablement.

${ }^{37}$ For epistemic devoir, see e.g. Huot (1974: 48) and Sueur (1979: 98).

38 A claim that is true without any doubt for the epistemico-modal use of certainement. 
difference ${ }^{39}$ The alternative explanation we propose has certain advantages (see further). Our hypothesis is that the impression of higher certainty expressed by certainemente is caused by the presence, in its lexical meaning, of a component that we propose to call "epistemic posture of certainty", a component that is absent from the meaning of both probablement and devoir (as we will see further). What is epistemic posture of certainty? It is an epistemic notion of a different nature than epistemic modality. Let us try to explain the differences between the two.

Epistemic modality refers to the qualification of the degree of certainty or probability of a propositional content (section 3.1). Linguistically expressing epistemic modality amounts to indicating how certain someone, typically the speaker or represented speaker, estimates her/himself about a propositional content, or indicating what epistemico-modal label is attached to a propositional content. Epistemic posture, on the contrary, refers to the radiation of confidence or self-assuredness by the speaker or (represented) speaker. Communicating epistemic posture amounts to showing to the hearer how certain one is, rather than to saying that. Epistemic posture is a kind of certainty the speaker shows or wants to show to the hearer; it is creating the impression or effect on the hearer that the speaker is certain ${ }^{40}$ ('Look how certain I am about what I am telling you!'), and this regardless of the epistemic label that is attached to that content. Epistemic posture of certainty is shown confidence, self-assuredness, certainty.

But what the speaker is confident or certain about, given the fact that what he communicated with certainemente, is but a hypothesis, something that is not certain? The speaker shows her/his confidence in the plausibility of her/his hypothesis; s/he shows her/his self-assuredness about her/his achievement in reaching a plausible hypothesis, about the excellence or superiority of her/his hypothesis above other plausible ones.

In her analysis of English surely, equivalent of certainemente, Downing (2001) uses formulations that are reminiscent of our definition of epistemic posture (underlined in the quotations):

Nevertheless, implications of superiority of knowledge on the part of the speaker are covertly present. A subliminal implication of surely is that the speaker has the more reliable knowledge, opinions or beliefs; indeed, that the speaker's opinion is the only true, reasonable or reliable one. Such a positioning, [...] is characteristic of a dominant speaker. (Downing 2001: 266-267, our emphasis)

The illusion is maintained [...] that the opinion voiced is the only true, reasonable or reliable one. (Downing 2001: 274, our emphasis)

Both epistemic posture of certainty (certainemente) and epistemic modality of certainty (certainement ${ }_{M}$ ) refer thus to forms of certainty, but they do not represent

\footnotetext{
${ }^{39}$ For devoir, this is even more difficult, because the verb belongs to a different grammatical category than certainementE.

${ }^{40}$ It could be considered the "perlocutionary" side of certainty.
} 
the same type of certainty: the one is shown certainty ${ }^{41}$ or confidence $(E)$, the other is estimated or expressed certainty (M). That difference is not always easy to detect in the data. Therefore, epistemic posture of certainty is easily confused with epistemico-modal certainty. The consequence of that is that some occurrences of certainement $t_{E}$ are easily taken as instances of certainement $t_{M}$.

Postulating a component of epistemic posture in the lexical meaning of evidential certainement has a series of benefits.

First benefit. It allows explaining the above-mentioned meaning difference between certainemente, on the one hand, and probablement and epistemic devoir on the other. By reducing the meaning of certainement $E$ to that of "probablement", one completely overlooks the posture of certainty present with certainement $E$ and absent with probablement. Indeed, by using probablement, the speaker explicitly indicates that her/his information is not certain, only probable. We assume that that explicit indication of the mere probable character of the information prevents the speaker from taking a posture of certainty regarding the content.

And epistemic devoir? Dendale (1994) argues that this verb points at the meticulous and patient process performed by the speaker in weighing the possible explanations for a given fact or possible answers to a question, before deciding on the most plausible one (e.g. in example 26c: We conclude that: "Plausibly, he thinks that I am stupid"). In that respect, epistemic devoir is opposed to the conjectural future ("Ce sera le facteur" ['That will be the postman']), which allows the speaker to "jump to conclusions", showing her/himself confident in the formulation of her/his conclusion ${ }^{42}$ (Cf. a doctor saying: "Ce ne sera qu'une petite toux innocente" ['It will be an innocent little cough']) (Dendale 2001). This amounts to saying that the conjectural future plausibly has posture of certainty in its lexical meaning, ${ }^{43}$ while epistemic devoir ${ }^{44}$ hasn't.

${ }^{41}$ This idea is similar to Anscombre's description of the French adverbs à coup sûr and bien sûr, when he says "les adverbes de phrase renvoient à une attitude qui est non pas décrite ou expliquée, mais montrée, jouée. En disant à coup sûr ou bien sûr, je ne présente pas ma certitude, je la montre, je me mets en scène comme plus ou moins assuré de la véracité de certains faits". (2013: 78, our emphasis) 'Sentence adverbs refer to an attitude that is not described or explained, but shown, played. By saying à coup sûr or bien sûr, I do not present my certainty, I show it, I stage myself as more or less assured of the veracity of certain facts.'

${ }^{42}$ Without using the term of posture of certainty, the analysis clearly hints into that direction.

${ }^{43}$ Another expression which has a suspected element of posture of certainty is je sais que 'I know that' when used in co(n)texts like "Je sais que c'est lui qui l'a fait" ['I know it's him who did it.'], where it is supposed to signal that the speaker is only speculating about who is guilty of a murder (with thanks to J.-Cl. Anscombre, who gave me the idea).

${ }^{44}$ We see at least two reasons why a speaker would prefer to have recourse to certainementE rather than to probablement or epistemic devoir when $\mathrm{s} /$ he is not totally certain of what $\mathrm{s} / \mathrm{he}$ is saying (but this topic needs further research): (a) s/he wants to appear cognitively "in control", not hesitant, confident, e.g. in order to be able the reassure the person $\mathrm{s} /$ he is speaking to: a doctor about a disease (see Dendale 2001 for a similar use of the conjectural future) saying: "Est-ce que ça peut nous aider? Je ne sais pas, mais ça ne peut certainement pas nous nuire" (frTenTen12) ['Can 
Second benefit. The notion of posture of certainty highlights what unifies this use of certainement with the other. The idea of maximum certainty is present in the two uses - and not only in the first, as suggests the literature - but in different ways: as "estimated degree of certainty" or as "shown confidence". This supports the polysemic nature of certainement - which does not block our homonymic treatment (advocated for reasons of effective categorization). It further allows linking evidential certainemente to the meaning of the composing adjective certain, better than can do analyses describing its lexical meaning in terms of mere probability or absence of (total) certainty (see section 1).

Third benefit. Since epistemic posture of certainty and epistemic modality of certainty represent dissimilar forms of epistemicity, describing the semantics of certainemente does not create a contradiction when postulating that content qualified by it is always interpreted as non-certain (section 4.2.2) and at the same time postulating that it expresses "postured" certainty (see especially example 23).

Fourth benefit. The notion of posture of certainty allows giving another, better justified, meaning to the qualification "weak modal" used in the literature (cf. section 1). Posture of certainty, because it is only shown certainty, is indeed a weaker form of certainty than the expressed certainty of epistemic modality. This weakening of epistemic modality of certainty into epistemic posture of certainty could offer an alternative to a diachronic explanation of the emergence of the "evidential" viz. "weak modal" use of certainement $t_{\text {. }}$

Fifth and last benefit. Since epistemic posture of certainty is a component that only some inferential evidentials seem to have in their meaning, it offers a possible distinctive feature for the description of expressions belonging to the paradigm of inferential evidential markers.

\section{THE INTERPRETATION IN CO(N)TEXT OF CERTAINEMENT}

The question we want to treat in this section is: How to know whether an occurrence of certainement in an utterance is an instance of certainemente or of certainement $_{M}$ ? We present three parameters and their respective values with respect to which elements of the $\operatorname{co}(\mathrm{n}) \operatorname{text}^{45}$ are interpreted as being in favour of certainemente or certainement $M$ (section 5.1). In section 5.2, we describe a series of

it help us? I don't know, but it certainly won't hurt us.']; (b) s/he is unwilling to search any further for an even more plausible and solid hypothesis (cf. the notion of "epistemic insouciance" by Cassam 2018), possibly because s/he does not consider the topic of conversation sufficiently important enough and wants to cut short any further discussion about the topic. Example (39) could be such a case.

${ }^{45}$ The indication co(n)text we use is meant to cover both the term cotext, frequently used in the French literature with the meaning of 'the elements present in the actual textual distribution of the studied word', and the term context, referring also to the extralinguistic, situational context (cf. Maingueneau 1996: s.v. cotext). 
$\operatorname{co}(n)$ textual configuration ${ }^{46}$ elements of which can be linked to the different parameter values.

\subsection{Parameters and their values for the interpretation of certainement}

Three parameters, linked to the above-described elements of the meaning of

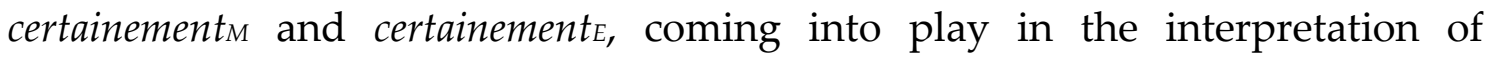
certainement are: Certainty, Truth status and Knowledge status. Each of them has two opposing values - except for Certainty, which has four. Each value points into the direction of one of the two uses of certainement (abbreviated below as $\mathrm{M}$ and $\mathrm{E})$.

As for the parameter Certainty, we saw big differences between the two uses of certainement in this regard. The two pairs of possible values of this parameter are: "total certainty" or "relative degree of certainty" (M) versus "non-certainty" (E) and "estimated and expressed certainty" (M) versus "shown certainty or confidence" (E). If an utterance containing certainement can be interpreted as expressing either total certainty (subjective or intersubjective) or a degree of certainty relative to or compared to another one, the adverb will most likely be interpreted as M. If, on the contrary, the utterance can be interpreted globally as expressing non-certainty, the adverb will be interpreted as E. These two values come into play at different levels of expression of meaning, as we saw: as a lexical meaning component for $\mathrm{M}$ and as a property of utterance meaning for $\mathrm{E}$, but that does not alter their impact on the interpretation of certainement.

The parameter Truth status has two possible values: "content already established as true for the speaker" (M) versus "content not yet or not clearly established as true for the speaker" (E). If an utterance containing certainement can be interpreted as expressing content that was already given in the co(n)text as true by the speaker, certainement is most likely to be interpreted as M. If it is clear that this is not the case or if it is not clear whether this is the case, certainement is to be interpreted as $\mathrm{E}$.

The opposing values of the third parameter, Knowledge status are called "knowledge in esse" (M) versus "knowledge in fieri" ${ }^{47}(\mathrm{E})$. Knowledge in esse (or "static knowledge") refers to the fact that the information communicated by the utterance is knowledge or belief that was already there, stored in the mind of the speaker. Certainement is then most likely to be interpreted as M. Knowledge in fieri (or "dynamic knowledge") refers to the fact that the information communicated by the utterance is presented as if it were "in the process of" being newly generated, or if it were just created through the speaker's guessing, presuming,

\footnotetext{
46 The same term is used by Downing (2001: 279), in her study on surely.

47 This distinction (together with in posse) was inspired by French linguist Gustave Guillaume, who used them for the description of tenses (Guillaume 1929).
} 
hypothesizing..., in short inferring. ${ }^{48}$ Certainement then is most likely to be interpreted as E.

The following table gives an overview of these parameters with the outcomes of their respective values:

\begin{tabular}{|l|l|l|}
\hline Parameter & M-Values & E-Values \\
\hline Truth status & Already established as true by S & Not (evidently) established as true by S \\
\hline $\begin{array}{l}\text { Knowledge } \\
\text { status }\end{array}$ & Memorized knowledge/ belief of S & Inferring knowledge by S \\
\hline Certainty1 & $\begin{array}{l}\text { - Total certainty for S } \\
- \text { Relative certainty for S }\end{array}$ & Non-certainty \\
\hline Certainty2 & Estimated and expressed certainty & Only shown certainty viz. confidence \\
\hline Result & => Epistemico-modal certainement & => Evidential certainement \\
\hline
\end{tabular}

The table shows that the respective values of the three parameters are contradictory. That means that the interpretation of certainement as evidential or epistemico-modal is an "either-or" question. The two uses of certainement can never coincide or merge into one single composite meaning, ${ }^{49}$ combining meaning elements of both uses, because their respective elements of meanings contradict each other for all parameters. ${ }^{50}$ If an equivocal co(n)text allows for two interpretations, these can never be activated in the mind at the same time, only in alternation.

Another conclusion that can be drawn from our analysis is that certainement cannot belong, neither in its epistemico-modal nor in its evidential use, to an "overlap category between modality and evidentiality" (1998: 86), ${ }^{51}$ of which van der Auwera \& Plungian postulate the existence, disagreeing with linguists for whom "modality does not encompass evidentiality 52 " (1998: 85) and stating:

\footnotetext{
"Inferential evidentiality is thus regarded as an overlap category between modality and evidentiality."

"The claim is only that the inferential reading [of a class of evidential expressions, PDD] amounts to epistemic modality and more particularly epistemic necessity." (1998: 85, our italics)
}

${ }^{48}$ I have always wondered why Willett (1988), in his trifold classification of evidentials, labelled one type Inferring (with -ing suffix), the other two Attested and Reported (with -ed suffix). The explanation could be that evidential inference is seen as an ongoing operation.

${ }^{49}$ This claim amounts to saying that certainement as a whole is not for us an "epistential", i.e. "an element that expresses evidentiality and epistemic modality simultaneously" (Faller 2002: 87). Even certainementE alone does not deserve that label because the lexical component of "epistemic posture" does not meet the functional definition of epistemic modality as given in section 3.1 (and most probably neither the formal one) and the meaning element of non-certainty is not part of the lexical meaning but emerges only at the utterance level.

${ }^{50}$ We made a similar claim about the evidential and non-evidential use of French adverb visiblement in Dendale, Vanderheyden \& Izquierdo Alegría (2020).

${ }^{51}$ For a similar position, but with a different argumentation, see Cornillie (2009: 51).

${ }^{52}$ See: "our decision to include inferential evidentiality under epistemic modality" (1998: 118). 
“Inferential evidentiality = epistemic necessity." (1998: 86)

In a functional perspective, the notions of evidentiality and epistemic modality are fundamentally different in nature (contrarily to what is claimed in the quotations above) ${ }^{53}$ and are not directly reducible ${ }^{54}$ to each other. In our perspective, inferring new knowledge, especially plausible knowledge, does not amount to labelling that knowledge for its degree of certainty, let alone as (epistemically) necessary. ${ }^{55}$ Vice versa, labelling knowledge epistemically as totally certain does not amount to signaling that it is inferred plausibly from other pieces of knowledge. The notion of epistemic necessity can at best only be directly relevant, in a functional analysis, for the lexical meaning of epistemico-modal certainement. Evidential certainement has no element of epistemic necessity in its meaning that can be considered to correspond directly to epistemic necessity: neither the type of inference it refers to (because it is non-deductive), nor the conclusion of the inference (because it is not necessarily true, but only plausible and defeasible, thus non-certain). ${ }^{56}$

Van der Auwera \& Plungian's claim, it seems, can be valid only within a logical or formal perspective, where deductive inference is used and where epistemic modality is defined in relation to the binary opposition necessity/possibility ${ }^{57}$ (see van der Auwera \& Aguilar 2016). In a formal perspective, the important functional difference between inference and epistemic necessity (Cornillie 2009: 47) is willingly sacrificed or ignored for the "higher" sake of a uniform description of polysemic items in terms of the invariant notions necessity and possibility.

\subsection{Co(n)textual configurations highlighting certain values of parameters}

Let us now see how elements of the co(n)textual configuration of certainement can be linked to one of the two values of the three parameters. We withheld a series of co(n)textual configurations through observation of our corpus examples. These are not exhaustive. It is not easy neither to univocally link elements of the $\mathrm{co}(\mathrm{n})$ textual configurations to the parameter values. Elements of the co(n)text often only hint towards an interpretation, while other elements of the co(n)text

${ }^{53}$ Unless categories does not refer to notions, but to sets of markers of these notions. But reading the third quotation as "Markers of Inferential evidentiality = would be blatantly false. Why would the authors indicate an overlap between markers of epistemic modality and markers of evidentiality by the sign " $=$ "?

${ }^{54}$ Both notions can be linked, however, through the notion of reliability (fiabilité in French). Dendale (1991: 33-37) devoted a section to that notion, considering the term of reliability, long before other scholars formulated similar ideas (Cornillie 2009, Wiemer 2018), as a "superordinate term", covering epistemico-modal, evidential and other properties (p. 36).

${ }^{55}$ We saw, on the contrary, that it does entail the non-certainty of the content.

${ }^{56}$ And also, the component of posture of certainty seems too far also from the idea of necessity.

57 "Reserving the term «modality» to just those domains in which possibility contrasts with necessity" (Van der Auwera \& Plungian 1998: 84). 
seem to overrule them. The linking of co(n)textual configurations with values of parameters can be seen as part of the interpretation process hearers perform in order to determine whether an occurrence of certainement is an instance of the evidential or of the epistemico-modal use.

\subsubsection{Configuration with elements relating to the Truth status parameter- M-value}

a) Categorical assertion

A first $\operatorname{co}(n)$ textual configuration is related to the M-value of parameter Truth status. In this configuration the content of the utterance containing the adverb is also expressed in an utterance that can be interpreted as true for the speaker, e.g. because it is the content of a full assertion. This orients the interpretation of the

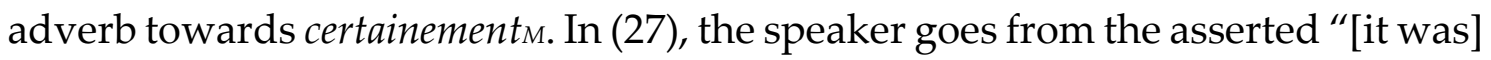
with a bit of distance" to the asserted "[it was] without distance" and then repeats and confirms this last version of her/his thought by the elliptical utterance containing certainement, meant to take away any doubt created by having changed his/her mind: ${ }^{5}$

(27) Ma nièce a dit, ça ne fait que commencer. Un peu sèchement peut-être, ou avec de l'humour et même un peu de distance. Non, sans distance. Certainement sans distance. (Kerman 2013, Frantext)

'My niece said, this is just the beginning. Maybe a little dryly, or with humor and even a little distance. No, without distance. Certainly without distance.'

A similar configuration can also be observed in the following examples, where a question gets a first answer in the form of oui/non - which will be interpreted, through the context that follows, as representing fully asserted utterances here. They are followed by a second answer, consisting of the adverb certainement in (28) or of certainement followed by the elliptical clause pas une injustice in (29). These answers are subsequently followed by strong supporting arguments for their respective answers: It is my fourth victory in (28); in I am the only one responsible in (29):

(28) Avec cette victoire dans Milan-San Remo, on peut dire que l'année 2010 commence fort pour vous? Oui, certainement. C'est ma quatrième victoire de l'année. (frTenTen12)

'With this victory in Milan-San Remo, can we say that the year 2010 starts strong for you? Certainly yes. It is my fourth victory of the year.'

\footnotetext{
${ }^{58} \mathrm{~A}$ reviewer suggested the possibility of an evidential reading here. This is not impossible. The speaker, using certainemente, signals in that case that he is beginning to hesitate her/himself and has to limit her/himself to the formulation of a mere hypothesis.
} 
(29) En tant qu'artiste solo, certains de vos albums ont échappé au public, qui n'y a pas adhéré. Y voyez-vous une injustice? Non, certainement pas une injustice. Je suis le seul responsable, je ne peux le reprocher à personne d'autre... (frTenTen12)

'As a solo artist, some of your albums have gone unnoticed by the public, who have not remained loyal. Do you see it as an injustice? No, certainly not an injustice. $\underline{\mathrm{I} \text { am }}$ the only one responsible, I cannot blame anyone else...'

A final, interesting, case is:

(30) Dans les bancs des facs [on] trouve des étudiants qui connaissent Chomsky? Certainement, on en trouve, mais assez peu. (frTenTen12)

'Do we find students on the university benches who know Chomsky? Certainly, you'll find some, but they are quite few.'

where certainement replaces a oui. It answers the Y-N question, as well as the subsequent assertion on en trouve does. The elliptic assertion "mais [on en trouve] assez peu" retroactively confirms the truth of on en trouve, making an interpretation as certainement $M$, rather than as certainement $t_{\text {, }}$ almost certain. ${ }^{59}$ Without the mais clause with its asserted content and without the comma after certainement, it would have been possible to see certainement as evidential (with on en trouve as the content of the hypothesis). The global utterance meaning would then have been: 'On doit en trouver' ['It must be possible to find some'].

b) Presupposition inside a wh-question

When certainement appears in the presupposed part of wh-questions, which is known to present itself as true, it adds a layer of subjective or intersubjective certainty to that truth, emphasizing it:

(31) Qu'est-ce qui appartient certainement à Freud et constitue l'originalité la plus profonde de son œuvre? Nous pouvons distinguer trois grandes contributions : [...]. (frTenTen12)

'What does certainly belong to Freud and does constitute the most profound originality of his work? We can distinguish three main contributions: [...].'

(32) Pourquoi cette vidéo va-t-elle certainement vous émouvoir ? (Internet ${ }^{60}$ )

‘Why will this video definitely move you?'

Other epistemico-modal adverbs would have been linguistically possible: probablement, peut-être. And in (32), one could replace the adverb by a "J'en suis

\footnotetext{
${ }^{59}$ The sentence initial position of the adverb and the fact that it is separated from the rest of the sentence by a comma constitute further arguments in favour of the certainement $t_{M}$ interpretation.

${ }^{60}$ Retrieved on 21/2/2019 from: <https://france3-regions.francetvinfo.fr/grand-est/champagneardenne/pourquoi-cette-video-50-millions-ues-va-forcement-vous-emouvoir-1626577.html>, (Franceinfo, régions, grand Est). Note that the hyperlink has forcément in it, which is even stronger than certainement.
} 
sûr" ['I am certain about that']. An evidential hypothesis interpretation seems excluded to us in that configuration.

c) Assertoric truth, "truth+" and the reason for use of certainement $_{M}$

Why does a speaker resort to the use of certainement $t_{M}$ instead of simply relying on the assertoric truth that a modally unmarked assertion automatically carries with? A beginning of an answer to this question can be found in Féron's observation (2002: 26) that certainement ${ }_{M}$

ne s'impose que si le locuteur a des raisons de renforcer son assertion. [...]. L'insertion d'un marqueur tel que $[. .$.$] certainement ("assurément") indique que le locuteur s'attend à des$ réserves de la part de son interlocuteur. [...] "Certainement a pour rôle de prévenir toute mise en question de l'assertion." 61 (Féron 2002: 26)

For English certainly, similar observations have been made by Mortenson (2006) and Simon-Vandenbergen \& Aijmer (2007). ${ }^{62}$ Our corpus data show that in co(n)texts where epistemico-modal certainement is used, there are often signs of doubt or uncertainty given by others than the speaker, or there is suspicion, on behalf of the speaker, that uncertainty may exist or arise (as in example 27). Certainement $t_{M}$ thus naturally occurs: after explicit questioning by a third party (as in example 29) or after the expression or evocation of an opinion contrary to the asserted content. In other words, a speaker will turn to certainement $t_{M}$ in co(n)texts where $\mathrm{s} /$ he is aware of uncertainty (or assumes uncertainty) in the minds or words of others about what $\mathrm{s} / \mathrm{he}$ is going to say. Since we have seen that certainement $\mathrm{M}_{\mathrm{M}}$ expressed total certainty of the speaker, it is important to underscore that this uncertainty or doubt cannot be his/hers. ${ }^{63}$ With the adverb, the speaker wants to explicitly counter possible uncertainty or doubt by clearly telling her/his certainty. The result is that an extra dimension of subjective or intersubjective certainty is superposed to the assertoric truth, turning it into something that could be called "enriched" truth. We will represent it as truth+ (see also Dendale 1990: 9, 1991: 144), where the " + " stands for the extra dimension of (inter)subjective certainty.

Our analysis of certainement ${ }_{M}$ as a marker of truth+ explains why we cannot subscribe to claims such as Halliday's for English certainly: "even a high value

${ }^{61}$ Certainement $_{M}$ "is only necessary if the speaker has reasons to reinforce his assertion. [...] The insertion of a marker such as [...] certainement $_{M}$ indicates that the speaker is expecting doubts from the other party. [...] The role of certainement is to prevent any challenging of the assertion" (Féron 2002: 26).

${ }^{62}$ Certainly "[t]ypically [...] places the speaker's proposition in implicit or explicit opposition to another $P O V$ [= Point of view], which may - but need not- be associated with the hearer" (Mortenson 2006: 98, our italics). It is "typical in discussion contexts where truth is not presented as selfevident or as shared knowledge" (cf. Simon-Vandenbergen \& Aijmer 2007: 211).

${ }^{63}$ This is different, as we will see further, with certainemente, where there is indeed uncertainty on the speaker's side. That is one of the differences between the two uses of the adverb. 
modal («certainly» $[\ldots])$ is less determinate than a polar form: that's certainly John is less certain than that's John" (1994: 89, our emphasis). ${ }^{64}$ Halliday's claim cannot apply to the epistemico-modal, or "total certainty" use of certainement $t_{\text {. }}$ Our analysis has shown that an utterance with certainement $t_{M}$ is not less certain than an unmarked asserted utterance in the indicative, but more certain, because it adds an extra layer of subjective certainty to the assertoric truth of the assertion in which it appears, turning it into a Truth+. Halliday's claim holds true, however, for the evidential use of certainement (certainementE). ${ }^{65}$

\subsubsection{Configurations relating to the Certainty parameter -M-value}

When the speaker draws the attention to the expression of the degree of certainty by comparing the degree of certainty of a certain content with that of another content, we most likely have to do with a case of certainement ${ }_{\mathrm{M}}$.

a) Certainement in the comparative form of superiority or inferiority

We have already seen this type of use in section 4.1. Here the speaker is most obviously trying to situate content on a scale of degrees of certainty and not making hypotheses. It is therefore a clear case of certainement $\mathrm{M}_{\mathrm{m}}$.

b) Comparing facts for their degree of certainty

When certainement is put into contrast with adverbs indicating lower degrees of certainty, like peut-être 'perhaps', probablement 'probably', vraisemblablement 'likely'... an epistemico-modal interpretation of the adverb is most likely. The comparison between the two contents is made on an epistemic scale, and the two adverbs draw the attention to that scale. This is the first reason to consider this an instance of certainement $t_{\mathrm{m}}$. Another reason is that certainement when several modal adverbs are present most often qualifies the highest certainty than does certainement $_{M}$ (cf. Gosselin 2010: 88-89). Two cases can be distinguished. In one case, the two epistemico-modal adverbs relate to the same content and are ordered from weak to strong, connected with (et) même '(and) even', e.g. (33). In the other case, the contents are different, (34):

(33) Il [Mitzaki] réalisa ensuite que sa méfiance était peut-être, même certainement, trop accrue, il avait omis la raison pour laquelle il était passé aussi facilement au poste frontière en arrivant : Yuki et Konoha sont en paix [...]. (frTenTen12)

\footnotetext{
${ }^{64}$ A similar claim has been made by Karttunen (1972: 12) about the modal verb must: with must, John must have left "intuitively [...] makes a weaker claim" than John has left (for other quotations and references in the same vein, see von Fintel \& Gillies 2010: 351-352).

${ }^{65}$ We suppose that in Halliday's example, certainly is most probably taken in its evidential use (meaning "That surely is John"), just as evidential must in Karttunen's example.
} 
'He [Mitzaki] then realized that his distrust had perhaps, even certainly, increased too much; he had omitted the reason why he had passed so easily at the border post upon arrival: Yuki and Konoha are at peace.'

(34) [Title of a scientific article:] Dubois, G. (1946). «Répartition des gisements certainement et vraisemblablement dinantiens dans la région de la Bruche». Comptes rendus sommaires de la Société Géologique de France, 12, 222-223. (GScholar)

"'Distribution of deposits in the Bruche region that are certainly and [others] plausibly Dinantian."'

In (34), the contrast is created by means of certainement versus vraisemblablement. Certainement qualifies the deposits that are $100 \%$ certainly of a certain type (Dinantian) and opposes them to deposits that are less certainly (only plausibly) of that type. Such a contrast can remain implicit, as in (35), also a title of a scientific article:

(35) Durand, J. M. «Affections extrahépatiques certainement liées au virus de l'hépatite C» La Presse médicale 26:21 (1997): 1014-1022. (Gscholar)

'Extrahepatic affections certainly linked to the hepatitis $\mathrm{C}$ virus.'

The illnesses that the author of the article in (35) (Durand) wants to study are those of which is known with certainty that they are linked to the virus of hepatitis $C$. They are contrasted with those that are not linked with certainty to that virus. If the adverb were to express only those that are suspected, presumed, conjectured, inferred to be linked to the virus, we bet that the author would have used probablement rather than certainement to avoid confusion with the total certainty interpretation, ambiguity being undesirable in the title of a scientific article. This isn't thus an evidential use of certainement.

c) Certainement in the negative concessive structure " $p$ mais certainement non $q$ "

Certainement very often appears in a clause with negated content that is part of a concessive structure introduced by the connector mais 'but'. 66 One of the (different) characteristics of a concessive structure is that it signals an exception to a "general" rule. That general rule, which normally remains implicit, links two contents, one of which is presented as something you can conclude from the other content. In (36) for example, the underlying general rule is "If I am a teacher, (you will normally conclude that) I am rich":

(36) Je suis certes enseignant mais certainement pas un nanti. (frTenTen12)67

'Sure, I am a teacher but certainly not a wealthy person.'

${ }^{66}$ The combination mais certainement pas... ['but certainly not...'] is particularly frequent in frTenTen 12 (more than 10500 occurrences).

${ }^{67}$ Certes functions here as a concessive marker rather than a modal marker. It must be clear also that certainement makes a stronger statement than certes. We did not study the latter adverb. 
The negated clause introduced by the concessive mais states the exception to the rule (e.g. "I am not wealthy"). This could have been done with a simple, modally unmarked, asserted clause, but the speaker preferred to use a clause containing certainement. This can be seen as adding extra epistemic force to that clause, to deny more vigorously the normal consequence of the general rule. Certainement has here its strong epistemico-modal meaning, a case, thus, of

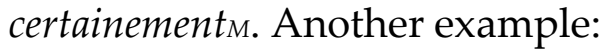

(37) L'assemblée est peut-être plus féminine, mais certainement pas féministe. (frTenTen12)

'The assembly may be more feminine but it is certainly not feminist.'

\subsubsection{Configurations relating to the Certainty parameter - E-value}

The E-value of the Certainty parameter predicts that we have an instance of certainemente when the certainty is not total and there is no comparison of degrees of certainty at stake. A typical configuration in that sense is what we call "co(n)texts of ignorance". When certainement is accompanied by an explicit confession of ignorance by the speaker (I don't know, I do not remember, no idea, ...) about what $s /$ he is saying, there is considerable chance that it is an evidential certainement signaling a hypothesis the speaker has to make by the lack of knowledge. In case of lack of stored knowledge, the only thing the speaker can do is guessing, making presumptions, plausibly inferring:

(38) Vince Carter s'est souvenu de ce dunk:68 «Que lui dirais-je si je le rencontrais aujourd'hui ? Je ne sais pas. Certainement que je suis désolé». (Google Actualités) ${ }^{69}$

'Vince Carter remembered this dunk: "What would I say to him if I met him today? I do not know. Certainly (Of course) that I am sorry."'

(39) [...] j’ai été élevée à terminer mon assiette, certainement pour de bonnes raisons, mais je ne me souviens pas desquelles. (frTenTen12)

'I was brought up to finish my plate, surely for good reasons, but I don't remember which ones.'

(40) [Talking about a jaguar XKR convertible] Avec intérieurs en cuir beiges, suréquipée, presque toutes les options, elle a certainement coûté une fortune ! Je dis certainement, car je n'ai aucune idée du prix. (frTenTen12) $)^{70}$

'With beige leather interiors, over-equipped, almost all options, it surely costs a fortune! I say surely because I have no idea of the price.'

\footnotetext{
${ }^{68}$ A famous dunk in basketball, where Carter scored while jumping over the shoulders of his opponent player, Weis.

${ }^{69}$ Retrieved on 18/1/2020 from: <https://lasueur.com/vince-carter-frederic-weis>.

${ }^{70}$ In this example, "Je dis certainement, car" ['I say surely because'] metalinguistically comments the status of hypothesis of what preceded by underscoring that the speaker does not have stored knowledge. It does not compromise the idea of posture of certainty.
} 
Even if what follows the expression of ignorance would be interpreted as a correction of what precedes, or if we deny that "Je ne sais pas, je ne me souviens pas, j'ignore, je n'ai aucune idée" are real markers of total ignorance (e.g. markers of uncertainty), it would seem contradictory, to read them as: "I do not know what I would say, ? but it is $100 \%$ certain that I would say sorry; I do not remember for what reasons I had to finish my plate, ${ }^{* *}$ but one thing is certain it was for good reasons"... It is thus difficult to claim that in these co(n)texts certainement expresses total certainty (M) about the contents: "I would say that I am sorry" in (38); "It was for good reasons (that I had to finish my plate)" in (39); "it has been very expensive" in (40). What accompanies those expressions of ignorance are clauses with the status of non-certain statements, typical of certainemente.

Example (40) is particularly interesting because it is a metalinguistic reflection of the speaker on the use of certainement, from which we understand that the adverb cannot mark total certainty for that speaker. This can even be turned into a test for the identification of evidential certainement: ${ }^{71}$

(41) a. I am not quite sure that $p^{\prime}$, so I say certainemente $p$ and not simply $p$.

b. It is only a hypothesis, so I say certainemente $p$ and not simply $p$.

\subsubsection{Configurations relating to the Knowledge status parameter-E-value}

Let us move on to a series of $\mathrm{co}(\mathrm{n})$ textual configurations related to the parameter of Knowledge status. Below is a list of contents that are impossible to obtain directly (by direct perception). When certainement combines with them, they signal that the content was inferred by the speaker. They strongly orient towards an interpretation as certainemente. It would be very difficult to consider certainement in those contexts as an instance of the epistemico-modal use.

a) Certainemente versus the unmarked asserted utterance

An utterance with certainement $E$ contrasts with an unmarked asserted utterance not only by the parameter of Truth status (as seen in section 5.1), but also by the (related) parameter of Knowledge status. The crucial opposition of values there is between knowledge (or belief) that is already stored by the speaker and considered "stabilized" (we call it "static" knowledge/belief) and knowledge that is inferred on the basis of evidence (we call it "dynamic" knowledge/belief):

(42) a. Mon collègue est là quelque part.

'My colleague is there somewhere.'

b. Mon collègue est certainement là quelque part.

'My colleague surely is somewhere over there.'

${ }^{71}$ I thank my colleague Antoon De Rycker for having suggested this test. 
(43) a. Il y a 300 places dans cette salle.

'There are 300 places in that room.'

b. Il y a certainement 300 places dans cette salle.

'There are certainly 300 places in that room.'

In many utterances with certainement, the adverb is there only to tell the hearer that the utterance is not just communicating previously memorized, already stabilized knowledge of the speaker, but information "freshly" created by the speaker by hypothesis, presumption, conjecture... on the basis of pieces of information (evidence). We then have instances of certainemente. A clear example is (14), reproduced here, where the inference is based on pieces of information introduced by puisque 'because' (in this case: the missing circumflex accents):

(14) Cette petite machine mécanique, où donc l'avait-il dégottée? Certainement pas apportée de France, puisque dans les pages du mémoire les accents circonflexes ont été rajoutés à la main sur l'original. (Perrut 2009, Frantext)

'Where did he find this little mechanical typewriter? Certainly not brought from France, since in the pages of the thesis, the circumflex accents were added by hand onto the original.'

It is important to note that even without certainement, one would recognize in (14) an inference made by the speaker on the basis of what can be interpreted as clues for the conclusion. The inference would then not be marked linguistically, however, but only contextually, through the coherence relations between sentences.

\section{b) Certainement and internal states of affairs of other people}

States of affairs that are internal to a person other than the speaker (like "you already know" in example 44) are -in the best case- directly accessible only to those who experience them. For others, they are "knowable" either via a report provided by the experiencer or via the speaker's abductive inference from external symptoms or by a default inference from generic knowledge:

(44) En ce qui concerne ma présence à la maison, vous savez certainement déjà par la presse que ce qui va se passer avec les étrangers se passera aussi avec moi. (Jablonka 2012, Frantext)

'Regarding my presence at home, you surely already know from the press that what is going to happen to foreigners will also happen to me.'

This explains the frequent use, in utterances describing such internal states of affairs, of either markers of inference or markers of report. Evidential certainement belongs to the first class. Thus, in (44), encyclopedic knowledge of the type "news circulates quickly" and in (45) specific knowledge about Anick's preferences allow the speaker to make presumptions or hypotheses, the 
epistemico-modal value of which, in the eyes of an interpreter and probably also the speaker, remains below total certainty:

(45) - Mange donc une tartine de confiture, Anick. Sers-là [sic], Lerouge, voyons ! - Je ne vois pas qu'Anick aime tellement les tartines, dit Lerouge. Elle préfère certainement une autre tasse de café. Pas vrai ? (Sarrazin 1965, Frantext)

'- So eat a slice of bread with jam, Anick. Help her, Lerouge, come on! - I don't see that Anick likes sandwiches so much, said Lerouge. She surely prefers another cup of coffee. No?'

Internal states of affairs do not need to be somebody else's. They can even be the speaker's own, because s/he may not be aware of the state of affairs or unable to describe it (cf. in example 46, "I am not aware of it"). In that case, it is clear that the speaker must also have inferred the content:

(46) Je réalise petit à petit que l'Écrivain m'aide à accéder à ma propre inspiration. Je m'appuie sur ses mots pour trouver les miens. Je suis certainement capable d'écrire toute seule, or je n'en ai pas conscience. (frTenTen12)

'I have gradually come to realize that the Writer is helping me to access my own inspiration. I rely on his words to find mine. I surely am able to write on my own, but I am not aware of it.'

c) Certainement and states of affairs situated elsewhere than at to or $\mathrm{mo}^{72}$

When certainement qualifies a proposition describing a state of affairs located in the past, e.g. (7), repeated here, and (47), in the future $(48)^{73}$ or in a non-actual possible world (49), the speaker may not have been or may not be capable of having direct access to the described state of affairs. Certainement indicates that $\mathrm{s} /$ he got access to it by inference, and it is most likely an instance of certainement::

(7) Les dernières vacances en France de mon père dataient de 1950. Une photographie, certainement prise par mon grand-père, montre ma grand-mère, les quatre enfants. (Audin 2012, Frantext)

'My father's last holiday in France was in 1950. A picture, surely taken by my grandfather, shows my grandmother, the four children.'

(47) Le corps de Tyrone Meehan a été retrouvé par la garda Síochána le jeudi 5 avril 2007, à 15 heures. Il était couché sur le ventre, dans le salon, devant la cheminée. Il revenait certainement de la forêt. Des branchages étaient éparpillés tout autour. Il portait sa veste et son écharpe. (Chalandon 2011, Frantext)

'Tyrone Meehan's body was found by the Garda Síochána on Thursday, 5 April 2007, at 3 p.m. He was lying on his stomach, in the living room, in front of the fireplace. He surely had come back from the forest. Branches were scattered all around. He was wearing his jacket and scarf.'

72 The symbols refer to the moment of speech $\left(\mathrm{t}_{\mathrm{o}}\right)$ and the actual (possible) world $\left(\mathrm{m}_{\circ}\right)$.

${ }^{73}$ See Miche \& Lorda: "This modal appears frequently in utterances in future [...] and conditional $[\ldots]$ tenses, since they refer to conjectures" (2014: 45). 
Without certainement, (7) would seem to communicate a content that the speaker simply retrieved from memory, which s/he considers memorized knowledge (without indication about how s/he acquired it). With the adverb, the speaker signals that the information was generated by her/him by a nonmonotonic inference. In both (7) and (47), the hypotheses concerning the person who took the picture and the place where the victim came from are formulated on the basis of perceived clues (grandfather not in the photo, branches scattered on the floor).

In the next examples, a prediction is made about the future or a possible imagined world. Certainemente draws the attention to the inferential-evidential and inherently uncertain character of the guess:

(48) D'ailleurs, le FN va certainement perdre ses voix : le rejet de toute valeur catholique par Marine Le Pen va faire fuir tout le vivier catholique qui avait fait la puissance du FN. (frTenTen12)

'By the way, FN will surely lose its votes: the rejection of all Catholic values by Marine Le Pen will scare away the whole Catholic pool that has made up FN's power base.'

(49) Par chance, il ne m'a pas choisi comme cobaye, j'aurais certainement dit des bêtises moi aussi. (Osmont 2012, Frantext)

'Luckily, he did not choose me as a guinea pig, I surely would have said dumb things, me too.'

\section{d) Certainement and generalizations}

When the utterance containing certainement constitutes a generalized statement and when it is clear that it was not possible or not very likely that all cases were observed, it is most likely a case of inferential certainement. Generalization or induction is a form of "inference" that can start from the observation of a limited number of cases:

(50) On lira ici et là, ailleurs et certainement partout, que Michel serait né à St-Rémy le jeudi 14 décembre 1503, «environ les 12 heures de midy» précise Chavigny (Janus, p. 1). (frTenTen12)

'We will read here and there, elsewhere and surely everywhere, that Michel was born in St-Rémy on Thursday, 14 December 1503, "around 12 o'clock midday" specifies Chavigny (Janus, p. 1).'

e) Certainement and causal explanations

Certainement is often used in utterances expressing causal explanations of states of affairs. Causality is immaterial and in se not perceivable, only inferable. Only the two events that are causally linked can, possibly, be perceived. In those cases, if certainement is used, it is to signal that the causal relation is a plausible hypothesis conceived by the speaker. It then is an instance of certainemente: 
(51) Les trackballs sont de moins en moins utilisés, certainement parce qu'ils sont moins intuitifs pour les débutants et sans doute ${ }^{74}$ aussi parce qu'ils occupent plus de place qu'une souris. (frTenTen12)

'Trackballs are used less and less, surely because they are less intuitive for beginners and no doubt also because they occupy more space than a mouse.'

(52) Arrivée sur le tartan, la douleur [dans le dos] avait disparu (certainement parce qu'il y a moins de chocs). (frTenTen12)

'Once arrived on the tartan, the pain [in the back] was gone (surely because there is less shock).'

\subsection{Some ambiguous examples}

The above-mentioned co(n)texts of interpretation are not always unidirectional as far as the interpretation of certainement is concerned. Sometimes two competing interpretations seem conceivable: certainement $t_{E}$ and certainement $\mathrm{c}_{\mathrm{M}}$. Let us comment some examples to show which elements of the context orient towards which interpretation of the adverb:

(53) Toutes ces femmes on les appelle des aides familiales. Et ma mère qui ne sait quasiment plus rien faire toute seule et certainement pas se laver ni s'habiller ni plein d'autres choses a droit à une aide familiale tous les jours. (Akerman 2013, Frantext)

'All these women are called family workers. And my mother, who can hardly do anything on her own anymore and surely not wash herself, get dressed, or many other things, is entitled to daily caregiving by a homeworker.'

In (53), the speaker asserts that his/her mother can do almost nothing by herself anymore. He then gives a small list of things that she isn't able to do anymore in an utterance containing certainement. The information given by the cotext is compatible with the two interpretations of certainement. Either the speaker observed his/her mother and knows, for having seen it, that she is not able to wash herself, get dressed and a few other things. In that case, certainement would be excluded and it would be a case of certainement $t_{M}$. Or s/he only guesses that these are amongst the things that she plausibly isn't able to do anymore. In that case it is an instance of certainemente.

In the next example, the utterance Je vous aime certainement can be either a strong assertion (true+) that the represented speaker loves his/her parents (paraphrasable as 'Cela est certain' ['That is certain']) - the most plausible interpretation - or a mere hypothesis s/he makes, not being sure, not knowing if $\mathrm{s} /$ he indeed still loves his/her parents because they get on his/her nerves. Certainement here remains ambiguous:

(54) Je ne viendrai pas mourir dans vos bras comme vous l'espérez en disant: «Papa Maman - je vous aime». Je vous aime certainement, mais vous m'énervez. Je veux crever tranquille, sans votre hystérie [...]. (Guibert 2007, Frantext)

\footnotetext{
${ }^{74}$ Note the second evidential marker, sans doute 'no doubt', plausibly also expresses epistemic posture of certainty (see also note 36 ).
} 


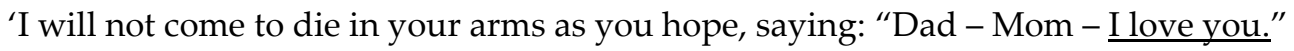
I certainly love you, but you get on my nerves. I want to die quietly, without your hysterics.'

\section{CONCLUSIONS}

The conclusion of this work is twofold. Firstly, it concerns the necessity to distinguish two uses for certainement, which leads to a double categorization of the expression, as evidential marker and as epistemico-modal marker. Secondly, it concerns the complexity of the semantics of the uses of certainement, especially the evidential use.

\subsection{Certainement: two uses, two types of marker}

The main objective of this study was to determine whether the so-called "modal" adverb certainement is to be categorized automatically and exclusively as an (epistemico-)modal marker, as its label would suggest. Our answer is negative. The semantic analysis of the adverb shows the existence of at least two main sentence adverb uses of certainement, different in nature. One signals the epistemico-modal labelling of the qualified content in terms of subjective or intersubjective degree of certainty. It has no other meaning component in its lexical meaning than that. The other was shown to be primarily evidential. It signals that the content qualified by the adverb is the result of a non-monotonic inferential operation, which is referred to in the literature by terms such as presumption, hypothesis, conjecture, surmise, supposition, guess... Its main characteristic is that it gives rise to conclusions that are (only) plausible and defeasible.

When the aim of a study is compiling a database or inventory of evidential markers according to an onomasiological approach ${ }^{75}$ (Wiemer 2018: 85), as in the EUROEVID project of Juana Marin-Arrese ${ }^{76}$ (see also Wiemer \& Stathi 2010), it is useful and practical to apply a homonymic treatment to items, like certainement, that have an identifiable evidential use besides other uses (e.g. an epistemicomodal one). That means accepting the idea of promoting the two uses of the adverb to separate lexical items (cf. Dirven 1973: 220) and putting them in two different inventories of epistemic "markers": certainemente in that of evidential markers and certainement $t_{M}$ in that of epistemico-modal markers. Such inventories allow more systematic in-depth comparisons of markers of the same subtype (e.g.

\footnotetext{
75 In an onomasiological perspective, different notions (in this case evidentiality or epistemic modality) are considered in terms of the forms that express these notions or integrate them as components in the semantic structure of the forms.

76 See <https://www.ucm.es/euroevidmod/>.
} 
for French comparing inferential evidentials like epistemic doit/devrait, the conjectural future, certainement, à coup sûr, sembler que, peut-être que, etc.).

Such a homonymic treatment is advisable here because of the contradictory meanings of the item (cf. louer 1 'borrow' and louer, 'lend'): total certainty versus absence of total certainty. It is further not uncommon in the field, but it remains often "undeclared". In studies on evidentiality for instance, devoir, with its deontic, alethic and epistemic uses (Kronning 1996, 2001), has also often got a homonymic treatment and it is clear that only the "epistemic" use should be taken into account for the categorization of that "modal" verb as an evidential. The same holds true for instance for the reportative use of the conditional in French.

\subsection{Complex semantics of the two uses of certainement}

Our study shows how complex the semantics of the adverb certainement is. First, it has two distinct uses, which, in the final analysis, resort to two different epistemic notions - at least from a functional, non-formal, perspectiveevidentiality and epistemic modality. Secondly, one of these two uses, the evidential use, has a complex semantics on its own. It has in its lexical meaning an inferential-evidential component, but also two, at first sight contradicting, epistemic elements of meaning. One was identified as the lexical meaning component of "epistemic posture" of certainty. The other as a "non-certainty" element (viz. "probability" element in dictionaries) expressed at the level of the utterance and linked to the non-monotonic nature of the inference in the evidential component. This explains why for us, the evidential meaning component is the main component and not the "probability" or "non-certainty" element. Thirdly, the interpretation of certainement should be seen as an either/or story: it is either evidential or epistemico-modal, never a merger of the two. This is due to the fact that the two uses have values that contradict each other at the level of each of the three parameters we distinguished for its interpretation in co(n)text (Certainty, Knowledge status and Truth status). Certainement conveys maximum certainty; certainemente non-certainty ("it is not (yet) completely certain that"). Certainement ${ }_{M}$ supposes stabilized, memorized knowledge, certainemente signals content newly created by hypothesis, presumption..., not yet stabilized into memorized knowledge and thus not yet definitely established neither as true. Certainement $t_{M}$ supposes that the qualified content is true, which cannot yet be the case for content qualified by certainemente.

\section{BIBLIOGRAPHY}

AIKHENVALD, A. Y. (2004), Evidentiality, Oxford, Oxford University Press.

ANDERSEN, H. (2016), "Abduction», in Cambridge Handbook of Historical Syntax, Roberts, I. \& Ledgeway, A. (eds.), Cambridge, Cambridge University Press, 301-321. 
ANSCOMBRE, J.-C. (2013), «À coup sûr et bien sûr et les fondements de la certitude», Revue de sémantique et pragmatique, 33-34, 67-98.

BACHA J. (1998), «'Bien sûr que je viendrai', Remarques sur les adverbes construits avec une completive», L'Information Grammaticale, 2, numéro spécial, 27-31.

BOYE, K. (2012), Epistemic meaning. A crosslinguistic and functional-cognitive study, Berlin/Boston, De Gruyter.

BYLOO, P., KASTEIN, R., \& NUYTS, J. (2006), «On certainly and zeker», Belgian journal of linguistics, 20(1), 45-72.

CASSAM, Q. (2018), «Epistemic insouciance», Journal of Philosophical Research, 43, 1-20.

CORNILLIE, B. (2009), «Evidentiality and Epistemic Modality: On the Close Relationship between Two Different Categories», Functions of Language, 16(1), 44-62.

DE HAAN, F. (1999), «Evidentiality and epistemic modality: setting boundaries», Southwest Journal of Linguistics, 18(1), 83-101.

DE HAAN, F. (2001), «The Relation between Modality and Evidentiality», in Modalität und Modalverben im Deutschen, Müller, R. \& Reis, M. (eds.), Hamburg, Buske, 201-216.

Dendale, P. (1990), «À propos de la vérité linguistique. Analyse argumentative et épistémique des prédicats vrai et certain», Travaux de linguistique, 20, 5-21.

DENDALE, P. (1991), Le marquage épistémique de l'énoncé: esquisse d'une théorie avec applications au français, $\mathrm{PhD}$ dissertation, Antwerp, University of Antwerp.

DENDALE, P. (1994), «Devoir épistémique, marqueur modal ou évidentiel ?», Langue française, 102, 24-40.

Dendale, P. (2001), «Le futur conjectural versus devoir épistémique: différences de valeur et restrictions d'emploi», Le français moderne, 69(1), 1-20.

DENDALE, P. (2018), «Évidentialité ou non-prise en charge ? Le cas du conditionnel épistémique en français : une réanalyse», Langue française, 200, 63-76.

Dendale, P., VANDERHEYDEN, A. \& IZQUIERDO AlegríA, D. (2020), «Visiblement en français, visiblemente en espagnol : des marqueurs évidentiels de perception directe ou d'inférence ?», in Marcadores del discurso y lingüística contrastiva en las lenguas románicas, Loureda, Ó. et al. (eds.), Madrid, Iberoamericana Vervuert, 63-96.

DESCLÉS J.-P. \& GUENTCHÉVA, Z. (2001), «La notion d'abduction et le verbe devoir "épistémique"», Cahiers Chronos, 8, 103-122.

DESCLÉS, J.-P. \& GUENTCHÉVA, Z. (2018), «Inference Processes Expressed by Languages: Deduction of probable Consequences vs Abduction», in Theorization and Representations in Linguistics, Arigne, V. \& Rocq-Migette, Chr. (eds.), Cambridge Scholars Publishing, 241-265 \& 315-317.

DiGNOIRE, C. (1969), «Observations concernant l'utilisation de l'adverbe certainement», Bulletin de la société roumaine de linguistique romane, 6, 41-50.

DIRVEN, R. (1973), «A performative approach to German 'sicher' and Dutch 'zeker'», in Linguistische Perspektiven. Referate des VII. Linguistischen Kolloquiums, Nijmegen, 26-30 September 1972, ten Cate, A. P. \& Jordens, P. (eds.), Tübingen, Niemeyer, 220-229.

DOWNING, A. (2001), «'Surely you knew!' Surely as a marker of evidentiality and stance», Functions of Language, 8(2), 253-285.

ETHERINGTON, D. W. \& CRAWFORD, J. M. (1999), «Toward Efficient Default Reasoning», in Logical Foundations for Cognitive Agents, Levesque, H. J. \& Pirri, F. (eds.), Berlin/Heidelberg, Springer, 137-150. 
FALler, M. (2002), Semantics and pragmatics of evidentials in Cuzco Quechua, PhD dissertation, Stanford, Stanford University.

FERON, C. (2002), «Le renforcement de l'assertion dans Le voir dit de Guillaume de Machaut», L'Information grammaticale, 92, 23-30.

FRAJZYNGIER, Z. (1985), "Truth and the indicative sentence», Studies in language, 9(2), 243-254.

FRANTEXT $=$ Base textuelle Frantext [online]. Nancy: ATILF, CNRS \& Université de Lorraine, 2019 [Access date: 21/05/2020]. Available at: <http://www.frantext.fr>.

FRTENTEN12 [online]. SketchEngine [Access date: 31/05/2020]. Available at: $<$ https://www.sketchengine.eu $>$.

GEZundHAJT, H. (2000), Adverbes en -ment et opérations énonciatives, Berne, Peter Lang.

GORIS, I. (2008-2009), Étude syntaxique et sémantique des adverbes certainement et sûrement, unpublished master thesis, Antwerp, University of Antwerp.

Gosselin, L. (2010), Les modalités en français. La validation des représentations. Amsterdam/New York, Rodopi.

GuENTCHEVA, Z. (1994), «Manifestations de la catégorie du médiatif dans les temps du français», Langue française, 102, 8-23.

Guillaume, G. (1929), Temps et Verbe, Paris, Champion.

GUIMIER, C. (1996), Les adverbes du français: le cas des adverbes en -ment, Gap/Paris, Ophrys.

HALLIDAY, M. (1994), Introduction to functional grammar, London, Edward Arnold.

HARMAN, G. (1965), «The Inference to the Best Explanation», The Philosophical Review, 74(1), 88-95.

HUOT, H. (1974), Le verbe DEVOIR. Étude synchronique et diachronique, Paris, Klincksieck.

KARTTUNEN, L. (1972), «Possible and must», in Syntax and semantics, Kimball, J. P. (ed.), vol. 1, New York, Academic Press, 1-20.

KOONS, R. (2017), «Defeasible reasoning», in Stanford Encyclopedia of Philosophy, Stanford, Center for the Study of Language and Information [Access date: 31/05/2020]. Available at: $<$ https://plato.stanford.edu/entries/reasoning-defeasible/>.

KRONNING, H. (1996), Modalité, cognition et polysémie : sémantique du verbe modal 'devoir', Uppsala, Acta Universitatis Upsaliensis.

KRONNING, H. (2001), «Pour une tripartition des emplois du modal devoir», Cahiers Chronos, 8, 67-84.

LYONS, J. (1977), Semantics, Cambridge, Cambridge UP.

MA, M. \& PIETARINEN, A.-V. (2018), «Let Us Investigate! Dynamic Conjecture-Making as the Formal Logic of Abduction», Journal of Philosophical Logic, 47, 913-945.

Maingueneau, D. (1996), Les termes clés de l'analyse du discours, Paris, Seuil.

MCDermont, D. \& DoYLE, J. (1980), «Non-Monotonic Logic I», Artificial Intelligence, 13, 41-72.

MCDOWELL, J. P. (1991), «Quasi-assertion», Journal of Semantics, 8, 311-331.

MEUNIER, A. (1974), «Modalités et communication», Langue française, 21, 8-25.

MiCHE, E. \& LORDA, C. U. (2014), «Probability and certainty markers in French and in Spanish (sans doute/sin duda)», Language and Dialogue, 4(1), 42-57.

MIECZNIKOWSKI, J. \& MUSI, E. (2015), «Verbs of appearance and argument schemes: Italian sembrare as an argumentative indicator», in Reflections on theoretical issues in argumentation theory, van Eemeren, F. H. \& Garssen, B. (eds.), Springer, Cham, 259-278. 
MOlinieR, C. \& LeVRIER, F. (2000), Grammaires des adverbes. Description des formes en -ment, Genève/Paris, Droz.

MOLINIER, Ch. (1990), «Une classification des adverbes en -ment», Langue française, 88, 28-40.

MoRGAN, Ch. (2000), «The Nature of Nonmonotonic Reasoning», Minds and Machines, 10, 321-360.

Mortensen, J. (2006), Epistemic and Evidential Sentence Adverbials in Danish and English. A comparative study, $\mathrm{PhD}$ dissertation, Roskinde, Roskilde University.

MusI, E. (2014), «Evidential Modals at the Semantic-Argumentative Interface: Appearance Verbs as Indicators of Defeasible Argumentation», Informal Logic, 34(4), 417-442.

NUYTS, J. (2001), Epistemic modality, Language, and Conceptualization, Amsterdam/Philadelphia, Benjamins.

PeIRCE, Ch. S. (1931-1935), Collected Papers of Charles Sanders Peirce, edited by Harteshorne, Ch. \& Weiss, P. (1974), vol. 1-6; by Burks, A. (1979), vol. 7-8, Cambridge/Massachusetts, The Belknap Press of Harvard University Press.

POLLOCK, J. L. (1987), «Defeasible Reasoning», Cognitive Linguistics, 11(4), 481-518.

POLYA, G. (1989), Comment poser et résoudre un problème?, Paris, Jacques Gabay.

REITER, R. (1978), «On reasoning by default», in Theoretical Issues in Natural Language Processing-2, Waltz, D. L. (ed.), Urbana, University of Illinois, 210-218.

Rescher, N. (2006), Presumption and the Practices of Tentative Cognition, New York, Cambridge University Press.

ReY-Debove, J. \& ReY, A. (1993), Le nouveau petit Robert, Paris, Dictionnaires Le Robert.

SimON-VANDENBERGEN, A. M. (2008), "Almost certainly and most definitely: Degree modifiers and epistemic stance», Journal of pragmatics, 40(9), 1521-1542.

SimOn-VAndenbergen, A. M. \& AimeR, K. (2007), The Semantic Field of Modal Certainty. Berlin/New York, Mouton de Gruyter.

StAGE, L. (2002), «Les modalités épistémique et déontique dans les énoncés au futur (simple et composé)», Revue romane, 37(1), 44-66.

STALNAKER, R. (1980/1993), «A note on non-monotonic modal logic», Artificial Intelligence, 64, 183-196.

SUEUR, J.-P. (1976), «Adverbes de modalité et verbes modaux épistémiques», Recherches Linguistiques, 5-6, 235-272.

SUEUR, J.-P. (1979), «Une analyse sémantique des verbes devoir et pouvoir», Le Français moderne, 47, 97-120.

TLFi = Le Trésor de la Langue Française informatisé [online]. Nancy: ATILF-CNRS \& Université de Lorraine [Access date: 31/05/2020]. Available at: <http://atilf.atilf.fr/>.

TRAUGOTT, E. C. (1989), «On the rise of epistemic meanings in English: An example of subjectification in semantic change», Language, 65(1), 31-55.

VAN DER AUWERA, J. \& AGUILAR, A. Z. (2016), «The History of Modality and Mood», in The Oxford handbook of modality and mood, Nuyts. J. \& van der Auwera, J. (eds.), Oxford, Oxford University Press, 9-27.

VAN DER AUWERA, J. \& PlungIAN, A. (1998), «Modality's semantic map», Linguistic Typology, 2, 79-124.

VION, R. (2001), «Modalités, modalisations et activités langagières», Marges linguistiques, 2, 209-231. 
VION, R. (2004), «Modalités, modalisations et discours représentés», Langages, 156, 96-110.

VON FiNTEL, K. \& GILLIES, A. S. (2010), «Must... stay... strong!», Natural language semantics, 18(4), 351-383.

WALTON, D. N. (2001), «Abductive, presumptive and plausible arguments», Informal Logic, 21(2), 141-169.

WIEMER, B. (2018), «Evidentials and epistemic modality», in Handbook of evidentiality Aikhenvald, A. Y. (ed.), Oxford, Oxford University Press, 85-108.

WIEMER, B. \& STATHI, K. (2010), "The database of evidential markers in European languages. A bird's eye view of the conception of the database (the template and problems hidden beneath it)», STUF, 63(4), 275-289.

WILLETT, Th. (1988), «A cross-linguistic survey of the grammaticalization of evidentiality», Studies in Language, 12, 51-97. 